\title{
Can “Zombie Enterprises” Find Self-Help Road through Technological Innovation?
}

\author{
Jingru Liang \\ School of Management, Jinan University, Guangzhou, China \\ Email: 2450532918@qq.com
}

How to cite this paper: Liang, J. R. (2017). Can "Zombie Enterprises" Find Self-Help Road through Technological Innovation? Chinese Studies, 6, 173-180.

https://doi.org/10.4236/chnstd.2017.63017

Received: June 12, 2017

Accepted: July 21, 2017

Published: July 24, 2017

Copyright $\odot 2017$ by author and Scientific Research Publishing Inc. This work is licensed under the Creative Commons Attribution International License (CC BY 4.0).

http://creativecommons.org/licenses/by/4.0/

\begin{abstract}
"Cutting overcapacity" is the primary task of supply-side structural reform in China, which focuses on "disposing and eliminating zombie enterprises firmly". "Zombie enterprises" usually refer to those who fall into a financial crisis but rely on the support of the government or the bank to survive. At present, the research of "zombie enterprise" by scholars at home and abroad is mainly concentrated in the macro level. But this paper argues that the enterprise is a specific market player, therefore, if you want to crack the "zombie enterprise" problem fundamentally, you should ultimately start from the enterprise, promoting the efficient use of resources through technological innovation, which helps enterprises to establish core competitiveness and drives the sustainable development of enterprises.
\end{abstract}

\section{Keywords}

Zombie Enterprise, Product Quality, Technology Innovation

\section{Research Background}

In recent years, overcapacity as one of the most important macroeconomic risks in China has become a general consensus. As the primary task of China's supplyside structural reform in 2016, it has gained wide attention from policy-making and economic circles, which focuses on "disposing and eliminating zombie enterprises firmly".

To clear the zombie enterprise, first of all we should clarify the definition of zombie companies. Recently, the executive meeting of the State Council pointed out that enterprises that have sustained losses for more than three years and did not meet the direction of structural adjustment should be cleared through asset restructuring, transfer of property rights, closing and bankruptcy. The industry defines it as an unwritten standard for zombie businesses. According to the pub- 
lic disclosure data in 2015, it shows that only with 3 year in a row, after deducting non-recurring profit and loss in earnings per share is negative as the standard, in our country, reduced to "zombie enterprises" a total of 266 companies, accounting for $9.5 \%$ of the total number of listed companies. For steel, cement and other industries with serious overcapacity, "zombie enterprises" accounted for more than $20 \%$. We can see that the situation of zombie enterprises in China is serious; so it is urgent to be dealt with (Chen Junjie \& Liu Zhibiao).

As China's economy slows, the weakest companies are on the verge of collapse. When they were unable to repay their bank loans, the firms were supposed to go bust, and the banks write off their loans and take on losses. But the reality is quite the opposite, under the behest of the Chinese government; the banking system is lending large amounts of money to zombie enterprises that are not economically profitable. Even as investors worry about the hard landing of China's economy, these "zombie companies" are dragging down the Chinese economy and may even push China's economy into a "lost ten years", as Japan has experienced.

The dangers of zombie companies are enormous. On the one hand, by the zombie enterprises on behalf of the backward production capacity cannot be eliminated, the problem of overcapacity is difficult to be fundamentally resolved; even if not curbed, it will bring greater harm to social and economic. On the other hand, when the government subsidies, bank loans and other social resources are flowing into the zombie enterprises, the enterprises with high production efficiency, good business conditions are difficult to obtain these resources. As a result, this resource mismatch will lead to "survival of the fittest", which will affect the long-term development of the economy.

\section{Research Significance}

In the 1980s, American Eastern Airlines was allowed to continue flying in the case of bankruptcy, which dragged down the US aviation industry. What's more, to save zombie enterprises, the Japanese economy has been lost for ten years. In order to prevent China from repeating the same mistakes, we must pay attention to the disposal of zombie enterprises. "Across the board" requires all zombie enterprises bankruptcy liquidation, will have serious adverse consequences. A considerable number of zombie enterprises can be restored to the normal state through external intervention or self-help measures. At present, the research of "zombie enterprise" by scholars at home and abroad is mainly concentrated in the macro level. However, in this paper, we argue that the enterprise is a specific market players, so how to deal with zombie companies, we should ultimately start with the enterprise and return to the enterprise itself. Most people may be ignored, why zombie companies will produce, in fact it is precisely because the enterprise operating performance is low for a long time. And then it led to the policy rescue by government through financial subsidies, credit support and other acts, and eventually cause "zombie enterprise" phenomenon (Caballero, Hoshi, \& Kashyap, 2008). 
Zombie is actually a kind of enterprise into a special financial distress and operating situation. Compared with the ordinary financial distress enterprise, the zombie enterprise is not lack of resources, but the occupied resources cannot produce the corresponding benefits, leading it cannot get rid of financial distress. Rawdanowicz et al. (2013) have shown that the presence of "zombie enterprises" leads to a decline in the investment of more efficient firms and produces "crowding out" effects. Lin et al. (2015) also hold a similar view: "zombie lending" is too large to increase the financial constraints of enterprises, hindering enterprises to invest in new ones. On the other hand, the existence of "zombie enterprises" will increase the intensity of competition in the industry and hinder potential entrants to the market. As for a normal company, even if it has an investment project of positive cash flow, it will not be easy to invest. However, since zombie enterprises received bank subsidized loans and had lower financial costs, so they were in a favorable position in the competition. They can take part in the market competition by increasing their salaries and reducing the price of their products, thus reducing the profit margins and distorting the normal market competition (Papava, 2010). If not properly deal with enterprise zombies, may lead to debt crisis, and even "zombie economy." If the zombie enterprises can self-help, it will effectively reduce the government's unnecessary expenses and improve government decision-making efficiency. At the same time, it will increase the utilization rate of capital flows, enhance the competitiveness of enterprises in the industry and reduce the bank settlement accounts to avoid financial risk.

Therefore, this paper takes the improvement of investment and management efficiency as a breakthrough point to study the impact of technological innovation on zombie enterprise. This paper argues that in order to fundamentally solve the problem of "zombie companies", allowing enterprises to long-term sustainable development, we must establish the core competitiveness of enterprises (Chen Qin, 2016). And technological innovation can promote the effective use of resources, drive the sustainable development of enterprises, and also contribute to the construction of the core competitiveness of enterprises for long-term development. Therefore, this paper intends to find the economic mechanism of zombified enterprise through the study of the relationship between technological innovation and zombie enterprises, so that we will have the opportunity to find ways to improve the status quo of zombies enterprises, to make enterprises on the right track, in normal operation and re-full of vitality.

\section{Literature Review}

The reasons for the formation of "zombie enterprises" in foreign literature focus on why banks are willing to provide loans to companies in financial distress. Most of the existing foreign research takes "zombie enterprises" in Japan as the main research object, so some of Japan's unique institutional factors have been more concerned about. In general, the main causes of "zombie enterprises" include the perverse incentive of banks to cover bad debts, the government's regu- 
latory forbearance, and close relationship between banks and enterprises under the main bank and the keiretsu system. The long-term low interest rate monetary policy and the government's improper rescue plan are the supporting forces that lead to the increasing and continuous existence of "zombie enterprises". Okamura (2011) argues that the lack of bank capital is the root cause of the "zombie" and validates this view through data from Japanese companies. Willam (2014) believes that in order to prevent banks from default, the government will tolerate and encourage banks to "zombie lending", prompting the "zombie enterprise" generated.

After 2000, the research on "zombie enterprise" has begun to emerge in the international academic circles, while the domestic research on "zombie enterprise" is scarce. At the same time, domestic studies are mostly policy-based studies or descriptive analysis, with few empirical analyses. He Fan \& Zhu He (2016) believes that adhering to the market-oriented principle is the basic orientation of dealing with zombie enterprises. Inefficiency is a typical characteristic of zombie enterprises, so one of the important objectives of dealing with zombie enterprises is to improve economic efficiency. Therefore, in the process of dealing with zombie enterprises, we must adhere to the market-oriented principle. In particular, to avoid the local government to maintain stability as an excuse to intervene in the disposal of zombie enterprises, delaying zombie enterprises disposal time. Nie Huihua, Jiang Ting, Zhang Yuxiao and Fang Mingyue (2016) analysis the problem of manufacturing Chinese zombie companies base on China industrial enterprise database. The study found that state-owned and collective enterprises in the proportion of zombies are the highest, while private enterprises, Hong Kong, Macao and foreign enterprises in the proportion of zombie enterprises are similar, which far less than the proportion of zombies in state-owned and collective enterprises. Large enterprises and medium-sized enterprises have the highest proportion of zombie enterprises and many zombie enterprises are old enterprises, coupled with the status of state-owned enterprises, large scale that is bound to bring a lot of challenges to the disposal of zombie enterprises. Cheng Hong and Hu Dezhuang (2016) conducted an empirical study on the mystery of zombies from the microscopic perspective by employing China Employer Employee Survey (CEES) dataset in 2015. Based on the result of Propensity Score Match (PSM), it is found that zombie firms are significantly lower than non-zombie firms in product quality capability, technological innovation capability and entrepreneurships. Therefore, it is suggested that in order to eliminate zombie firms, great attention should be paid to enterprises' inner factors. Zhu Shunnan and Chen Chen (2016) used Logit model to analyze the forming factors of "zombie enterprise" in china and then find that high debt, large scale, manufacturing and state-owned enterprises are more likely to become zombie enterprises", and low operating efficiency is the main reason for the enterprises in the energy extraction and manufacturing enterprises to become "zombie enterprises".

The existing literature have done a lot of research on the mechanism of the 
"zombie enterprises" from the point of market withdrawal obstacles, but only consider form the external macro policy factors, while the internal microcosmic factors is not in-depth research. In fact, why zombie companies will produce, it is precisely because the enterprise operating performance is low for a long time, which led to the policy rescue by government and eventually cause "zombie enterprise" phenomenon. The study of the internal micro factors of "zombie enterprise" will further improve and enrich the theoretical understanding of the "zombie enterprise" puzzle in the domestic and foreign academic circles.

\section{Technological Innovation Is an Important Self-Help Way of "Zombie Enterprise"}

"Zombie enterprises" usually refers to those who fall into a financial crisis but rely on the support of the government or the bank to survive. In China, with the development of economy in recent years, the credit bubble created by the economic bubble has provided an environment for the breeding of zombie enterprises. State-owned enterprises are unclear in responsibility and inefficient, and the government is worried about the resettlement of workers and staff, and blind support for them. What's more, relevant departments supervision is not enough, the company should be delisted still active in the capital market. Different from the enterprises with the problem of troubled assets, "zombie enterprise" is characterized by the long-term and dependency of "blood sucking".

At present, the state attaches great importance to building a favorable external environment for enterprise development, and adopts measures such as decentralization and tax reduction, but the internal issues of concern is not high enough. In fact, the biggest problem of zombie enterprises lies in the misallocation of resources, in other word, the resources occupied by the zombie enterprises cannot produce corresponding benefits, and do not have the ability to get rid of financial difficulties. Therefore, to remove the "zombie", the most fundamental thing is to increase the endogenous power of enterprises.

Due to incomplete information and path dependence, some enterprises cannot transition from the growth path of "tide investment" to the "quality innovation" development stage (Li Tang, 2016), which cannot meet the effective demand of the market, resulting in operating performance decline and even long-term losses, and may cause "zombie enterprises" phenomenon. The low product capability often reflects the lack of primary and endogenous technological innovation capability of enterprises. Since the reform and opening up, China's economic growth pattern has shown. China's economic growth mode has shown obvious speed growth driven by the scale factor. Since the reform and opening up, China's economic growth mode has shown a significant factor in the growth factor driven by the scale factor. The contribution of tangible capital and labor to economic growth is too high, while the contribution of human capital, technological progress and structural change to economic growth is low, and economic growth is at the expense of substantial material consumption and labor input (Chen Hong, 2014). In recent years, overseas shopping has been hot. 
According to the data of the Ministry of Commerce, nowadays, Chinese tourists spend more than one trillion yuan abroad every year, and the outflow of consumption has become a phenomenon that cannot be ignored. This shows that domestic demand is huge, but the lack of technical innovation restricts the enterprise product renewal speed and product quality level, so that enterprises cannot meet the changing needs of the market and the formation of differences in the quality of the competitive advantage, which led to a decline in business performance, increase the possibility of zombie (Lin Yifu, Wu Hemao, \& Xing Yiqing, 2010). Experts said the improvement in quality is an important step in actively adapting to the trend of consumption upgrades and accelerating the supply-side reform of the real economy. In the short term, we can guide consumers to keep more consumer demand at home through tax reform and product promotion. In the long run, we will give full play to the decisive role of the market in resource allocation, improve the incentive mechanism such as intellectual property protection, promote the reform of vocational education and the cultivation of professional spirit through the way of reform, so as to build the foundation for the promotion of high quality products and services.

The report of the 18th Party Congress clearly pointed out that under the socialist market economy transition system, it is very important to implement the development strategy of innovation. Especially for enterprises, it is necessary to establish a technological innovation system. Technological innovation is closely related to the strategic layout and the long-term business interests of an enterprise, which can be investigated as the core competitiveness of an enterprise. Thus, it can be seen that technological innovation can drive the sustainable development of enterprises and help establish the core competitiveness of longterm development of enterprises, so as to reduce the possibility of enterprise zombified. On the contrary, the deficiency of technology innovation will restrict the speed of product updating and upgrading the level of product quality, so that enterprises cannot meet the changing needs of the market and hard to form a differentiated quality competitive advantage, which led to a decline in business performance, increase the possibility of zombies.

\section{Conclusion and Suggestion}

The results of the previous analysis show that the key to the existence of "zombie enterprises" lies in the low quality of products and thus cannot meet the increasingly prominent individualized and differentiated quality requirements of consumers, which causes that the enterprise production supply cannot be transformed into consumers' real purchasing needs, and resulting in a state of non obvious market clearing. Therefore, in order to eliminate the phenomenon of "zombie enterprise", it is very important to activate the endogenous growth momentum of enterprises through product quality innovation. To this end, the following recommendations are made.

In the case of zombie enterprises, the government should reduce its intervention in the market and make the market to play a decisive role in the allocation 
of resources. On the other hand, the government should also play a positive role. First of all, it should build a fair and just market competition order, effectively stimulate the endogenous motivation of enterprises to pursue quality and make the quality strategy such as standard, certification and brand become the core competitive strategy that entrepreneurs attach great importance to, so that enterprises will consciously meet the new market demand through continuous quality innovation. Secondly, in view of the weak innovation foundation of the small and medium-sized enterprises, the government should increase the input of basic research projects and industrial generic technology to promote the spillover of technological innovation. At the same time, the government should cultivate and develop intermediary service institutions for technological innovation which can provide a whole set of services for technological R\&D, scientific research management and property right transaction of enterprises, so as to clear up the obstacles to technological innovation in small and medium-sized enterprises.

As for the enterprise itself, it is necessary to activate its endogenous growth momentum through product quality innovation to get rid of the situation of zombie. The enterprise should not only pay attention to the digestion and absorption of imported technology and imitation innovation in order to narrow the gap with the developed countries as soon as possible, but also increase investment in basic research, attach more importance to the self accumulation of knowledge, and then seek original technological innovation, thereby gain a competitive edge in the world market (Benhabib, Perla, \& Tonetti, 2014).

\section{Limitations of Research}

At present, most of the domestic literature only considers the external macroeconomic policy factors of "zombie enterprises". Although this paper studies the internal microcosmic factors of "zombie enterprises", the research is not deep enough. Since there is no clear standard for the definition of zombie enterprises in the academic world, the definition of zombie enterprises can be mistaken. In addition, domestic studies are mostly policy-based studies or descriptive analysis, with few empirical analysis. In future studies, we can use empirical analysis to verify the relationship between the two. We hope that we can further improve and enrich the theoretical cognition of domestic and foreign scholars about the mystery of "zombie enterprise".

\section{References}

Benhabib, J., Perla, J., \& Tonetti, C. (2014). Catch-Up and Fall-Back through Innovacation and Imitation. Journal of Economic Growth, 19, 1-35.

Caballero, R. J., Hoshi, T., \& Kashyap, A. K. (2008). Zombie Lending and Depressed Restructuring in Japan. American Economic Review, 98, 1943-1977.

Chen Hong. 程虹. (2014). China's Economic Growth: Transition from Velocity Era to Quality Era 我国经济增长从“速度时代”转向“质量时代”. Journal of Macro-Quality Research, 4, 1-12.

Chen Junjie, \& Liu Zhibiao. 程俊杰, 刘志彪. (2015). Overcapacity, Factor Distort and 
Economic Fluctuations: Empirical Evidence from China 产能过剩、要素扭曲与经济 波动一来自制造业的经验证据. Economist, 11, 59-69.

Chen Qin. 陈琴. (2016). Micro Thinking of “Zombie Enterprise” 处置“僵尸企业”的微 观思考. Finance Resource, 6, 36-37.

Cheng Hong, \& Hu Dezhuang. 程虹, 胡德状. (2016). The Mystery of Zombies: An Empirical Study from a Microscopic Perspective: Evidence from China Employer Employee Survey (CEES) 僵尸企业存在之谜: 基于企业微观因素的实证解释. Journal of Macro-Quality Research, 1, 7-25.

He Fan, \& Zhu He. 何帆, 朱鹤. (2016). The Identification and Response of Zombie Enterprises 僵尸企业的识别与应对. Expert Forum, 5, 20-22.

Li Tang. 李唐. (2016). Demand Oriented Quality Innovation 围绕需求变化推进质量创 新. Renmin Daily 人民日报.

Lin Yifu, Wu Hemao, \& Xing Yiqing. 林毅夫, 巫和檚, 邢亦青. (2010). “Wave Phenomena” and Formation of Excess Capacity “潮涌现象”与产能过剩的形成机制. Economic Research Journal, 10, 4-19.

Lin, Y., Srinivasan, A., \& Yamada, T. (2015). The Effect of Government Bank Lending: Evidence from the Financial Crisis in Japan. Working Paper.

Nie Huihua, Jiang Ting, Zhang Yuxiao, \& Fang Mingyue. 聂辉华, 江艇, 张雨潚, 方明 月. (2016). The Status Quo, Causes and Countermeasures of Zombie Enterprises in China 我国僵尸企业的现状、原因与对策. Macroeconomic Management, 9, 63-88.

Okamura, K. (2011). “Zombie” Banks Make “Zombie” Firms. Working Paper.

Papava, V. G. (2010). The Problem of Zombification of the Postcommunist Necroeconomy. Problems of Economic Transition, 4, 35-51.

Rawdanowicz, L., Bouis, R., \& Watanabe, S. (2013). The Benefits and Costs of Highly EXpansionary Monetary Policy. Working Paper, No. 1082.

Willam, D. (2014). Zombie Banks and Forbearance Lending: Causes, Effects, and Policy Measures. Leipzig: Universität Leipzig.

Zhu Shunnan, \& Chen Chen. 朱舜楠, 陈琛. (2016). Incentives and Disposal of “Zombie Enterprise” “僵尸企业”诱因与处置方略. Macro Economy and Micro Operation, 3, 110-119.

Submit or recommend next manuscript to SCIRP and we will provide best service for you:

Accepting pre-submission inquiries through Email, Facebook, LinkedIn, Twitter, etc. A wide selection of journals (inclusive of 9 subjects, more than 200 journals)

Providing 24-hour high-quality service

User-friendly online submission system

Fair and swift peer-review system

Efficient typesetting and proofreading procedure

Display of the result of downloads and visits, as well as the number of cited articles

Maximum dissemination of your research work

Submit your manuscript at: http://papersubmission.scirp.org/

Or contact chnstd@scirp.org 